\title{
Sol-gel bioceramic material from bentonite clay
}

\author{
Enobong R. Essien ${ }^{1}$, Luqman A. Adams ${ }^{2 *}$, Rafiu O. Shaibu ${ }^{2}$, Aderemi Oki ${ }^{3}$ \\ ${ }^{1}$ Department of Chemical Sciences, Bells University of Technology, Ota, Nigeria \\ ${ }^{2}$ Department of Chemistry, Faculty of Science, University of Lagos, Lagos, Nigeria \\ ${ }^{3}$ Department of Chemistry, Prairie View A \& M University, Prairie View, USA \\ Email: ladams@unilag.edu.ng
}

Received 20 December 2012; revised 5 January 2013; accepted 15 January 2013

\begin{abstract}
Bioceramic material of the quaternary system; $\mathrm{SiO}_{2}$ $\mathrm{CaO}-\mathrm{Na}_{2} \mathrm{O}-\mathrm{P}_{2} \mathrm{O}_{5}$ that has composition similar to Bioglass $^{\circledR} 45 \mathrm{~S} 5$ was prepared by the sol-gel method from locally obtained bentonite clay (BTC). The monolith obtained was sintered at $1000^{\circ} \mathrm{C}$ for $2 \mathrm{~h}$ to facilitate densification and phase transformation. $\mathrm{X}$-ray diffraction (XRD) analysis revealed the presence of sodium calcium silicate, $\mathrm{Na}_{2} \mathrm{Ca}_{2} \mathrm{Si}_{3} \mathrm{O}_{9}$ as major crystal phase, and another secondary orthorhombic phase, $\mathrm{NaCaPO}_{4}$. Fourier transform infrared (FTIR) spectroscopic investigation confirmed the presence of Si$\mathrm{O}$-Si bonds and a crystalline phosphate in the glass network. Scanning electron microscopy (SEM) revealed a network of micropores and interconnected macropores. Overall, the material displays features amenable for possible utilization in tissue engineering scaffolds.
\end{abstract}

Keywords: Bioceramic; Sol-Gel; Monolith; Bentonite Clay; Silica

\section{INTRODUCTION}

The number of patients requiring and receiving biomedical implants to correct defects and heal diseases of the skeletal system is constantly increasing [1]. Tissue engineering and regenerative medicine assist with restoration of damaged tissues using both functional cells and biodegradable scaffolds made from engineered biomaterials $[2,3]$. Significant efforts in the last decades have been devoted to the fabrication of porous and highly interconnected bioceramic scaffolds based on hydroxyapatite (HA), tricalcium phosphate and related composite materials for application in bone tissue engineering [4-6].

In this regard, Bioglass ${ }^{\circledR} 45 \mathrm{~S} 5$ characterised with high amounts of $\mathrm{Na}_{2} \mathrm{O}$ and $\mathrm{CaO}$, and relatively high $\mathrm{CaO} / \mathrm{P}_{2} \mathrm{O}_{5}$ ratio [7] has shown capacity to induce favourable intracellular and extracellular responses promoting rapid bone

\footnotetext{
"Corresponding author.
}

formation [8-11] through formation of a hydroxycarbonate apatite (HCA) layer.

The major approaches to processing bioactive glass materials include; the melting and the sol-gel methods. The melting method utilizes high temperature in the range of $1300^{\circ} \mathrm{C}-1400^{\circ} \mathrm{C}$, while a major advantage of the sol-gel method is the much lower processing temperature, coupled with the ability to control the compositional range of the glass [6].

A major limitation of bioactive glasses, especially in the porous form is that they display low mechanical properties compared to cortical and cancellous bone $[12,13]$, thus restricting their wide range of applications.

Some previous efforts $[14,15]$ have shown that when sintered under optimal conditions, sodium containing bioglass attains nearly full densification and produces fine crystals of $\mathrm{Na}_{2} \mathrm{Ca}_{2} \mathrm{Si}_{3} \mathrm{O}_{9}$ having high bioactivity index [16] to give scaffolds with competent mechanical strength.

The serious challenge to the large scale preparation of bioactive glasses and glass-ceramic materials is the high cost of the widely used alkoxide precursors such as; tetraethyl orthosilicate (TEOS) and tetramethyl orthosilicate (TMOS) [17-20]. Consequently, some authors like Nayak et al. [21], Wu et al. [22] and Zanotto et al. [23] have explored alternative silica sources in their pathway to large scale bioactive glasses.

Clay minerals are fine grained hydrous silicates of octahedral or tetrahedral layered arrangement. Their chemical composition implies that they may yet serve as an economically viable non-toxic silica source for large scale synthesis of bioactive glasses.

Bentonite clay; $(\mathrm{Na}, \mathrm{Ca})(\mathrm{Al}, \mathrm{Mg})_{6}\left(\mathrm{Si}_{4} \mathrm{O}_{10}\right)_{3}(\mathrm{OH})_{6} \cdot \mathrm{nH}_{2} \mathrm{O}$ formed from the weathering of volcanic ash is naturally occurring sedimentary clay with the 3-layered clay structure. It displays one aluminium oxide sheet sandwiched by two silicon oxide sheets Figure 1 [24]. Structurally, the internal aluminium and external silicon oxide sheet share oxygen atoms, while $\mathrm{Mg}^{2+}$ ions often substitute for $\mathrm{Al}^{3+}$ ions resulting in net negative charge [25]. The charge in the platelet is balanced by counter ions, usually 


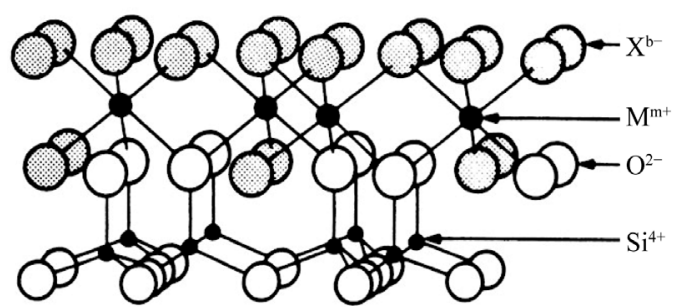

1:1 LAYER

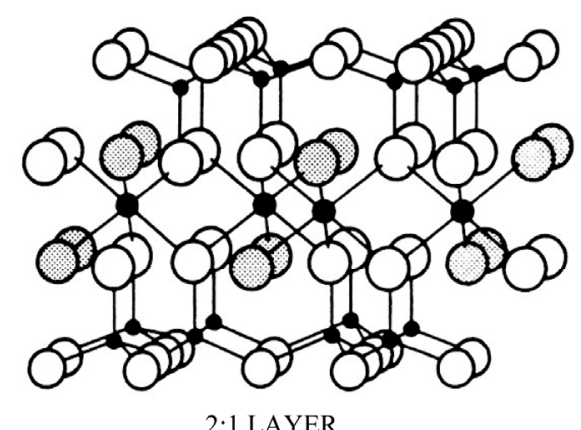

(a)

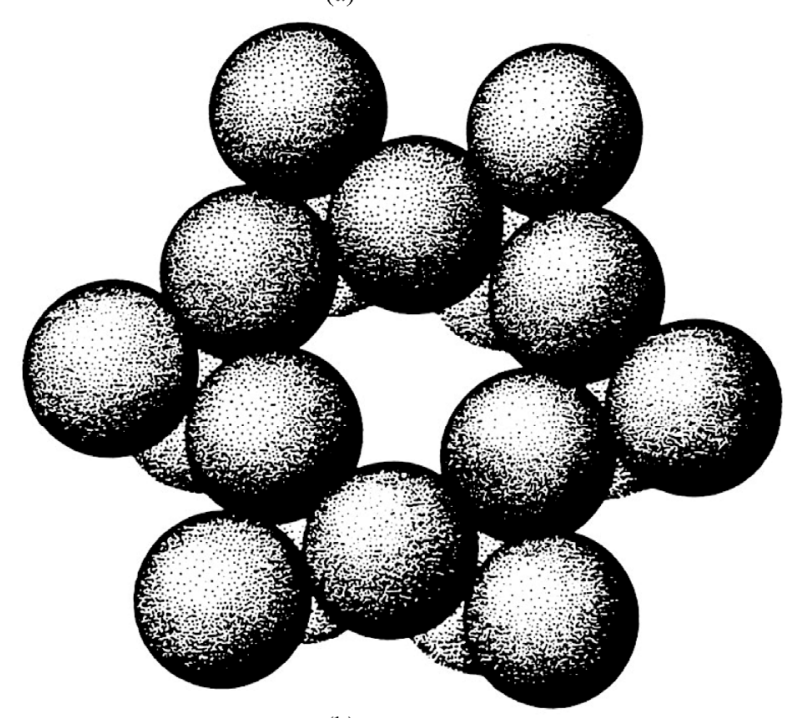

(b)

Figure 1. Crystal structure of clay mineral showing (a) $1: 1$ and 2:1 layer type clay, where $\mathrm{X}$ (shaded circles) is usually $\mathrm{OH}$ and $\mathrm{M}$ can be $\mathrm{Al}, \mathrm{Mg}, \mathrm{Fe}$, etc; (b) Siloxane cavity in the basal plane of a tetrahedral sheet [24].

$\mathrm{Na}^{+}$and $\mathrm{Ca}^{2+}$ located between the platelets. Clay has a wide origin and is particularly cheap and widely available in Nigeria [26]. The silicon oxide layer can be extracted using alkali at elevated temperature to give the corresponding alkali silicate as possible precursor for glass synthesis.

In this research work, we focus on the use of sodium bentonite as a source of silica to prepare sodium containing bioceramic material similar in composition to Bioglass ${ }^{\circledR} 45 \mathrm{~S} 5$ quaternary system via the sol-gel process. To the best of our knowledge the use of bentonite clay as a precursor for this type of bioceramic has not been previously reported in literature.

\section{MATERIALS AND EXPERIMENTAL PROCEDURES}

\subsection{Materials}

The following chemicals were used as obtained for the preparation of the bioceramic material; bentonite clay$(\mathrm{OH})_{4} \mathrm{Si}_{8} \mathrm{Al}_{4} \mathrm{O}_{20} \cdot \mathrm{nH}_{2} \mathrm{O}$ (obtained locally), nitric acid (Fluka, Germany), phosphorus pentoxide (BDH Laboratory, 98\%), sodium nitrate (Sigma-Aldrich, 99\%), and calcium nitrate tetrahydrate (LOBA, 98\%).

\subsection{Experimental Procedures}

The bioceramic material with composition (wt $\%) ; 45$ $\mathrm{SiO}_{2}, 24.5 \mathrm{Na}_{2} \mathrm{O}, 24.5 \mathrm{CaO}, 6 \mathrm{P}_{2} \mathrm{O}_{5}$ was prepared through the sol-gel process using bentonite clay as precursor. According to the extraction procedure reported by Essien et al. [26], a mixture of bentonite clay (13.33 g) in $1 \mathrm{M}$ $\mathrm{NaOH}(250.00 \mathrm{ml})$ was heated at $120^{\circ} \mathrm{C}$ for 2 hours under reflux in a round bottom flask. The filtrate obtained was slowly evaporated to dryness at $130^{\circ} \mathrm{C}$ to obtain sodium metasilicate $\left(\mathrm{Na}_{2} \mathrm{SiO}_{3}\right)$. In a typical gel-derived procedure for preparing Bioglass ${ }^{\circledR} 45 \mathrm{~S} 5$ [15], $\mathrm{Na}_{2} \mathrm{SiO}_{3}$ $(9.00 \mathrm{~g})$ was dissolved in deionised water $(15.00 \mathrm{ml})$ to give a solution that was then added slowly to $1 \mathrm{M} \mathrm{HNO}_{3}$ $(15.50 \mathrm{ml})$ in a beaker furnished with a magnetic stirrer under ambient temperature for 1 hour to facilitate complete hydrolysis. Thereafter, $\mathrm{P}_{2} \mathrm{O}_{5}(0.59 \mathrm{~g}), \mathrm{NaNO}_{3}(0.37$ g) and $\mathrm{Ca}\left(\mathrm{NO}_{3}\right)_{2} \cdot 4 \mathrm{H}_{2} \mathrm{O}(10.16 \mathrm{~g})$ were added respectively under constant stirring. Each of those three reagents was allowed 45 minutes to react. After complete addition, the mixture was further stirred for additional $1 \mathrm{~h}$ to afford a gel. The resulting gel was aged at room temperature for 5 days, dried at $60^{\circ} \mathrm{C}, 200^{\circ} \mathrm{C}$, and $600^{\circ} \mathrm{C}$ for 72,40 and 5 hours respectively, followed by sintering at $800^{\circ} \mathrm{C}$ for 3 hours and $1000^{\circ} \mathrm{C}$ for 2 hours.

\subsection{Methods of Characterization}

Atomic absorption spectroscopy (AAS) Perkin Elmer A Analyst 200 was used to determine elemental composition of the finally sintered material. Further evaluation was by X-ray diffraction (XRD, X'pert PRO PANalytical) using $\mathrm{CuK} \alpha$ radiation (0.154060) source operated at $40 \mathrm{kV}$ and $40 \mathrm{~mA}$. The diffraction patterns were obtained in the $2 \theta$ range from $5^{\circ}-120^{\circ}$. The morphology of the material was investigated using scanning electron microscopy (SEM, EVO/MAIO). The sample was carboncoated and observed at an accelerating voltage of $10 \mathrm{kV}$. Fourier transform infrared (FTIR, Perkin Elmer Spectrum X), with the wavenumber range of $4000-400 \mathrm{~cm}^{-1}$ employing $\mathrm{KBr}$ pellets operating in a reflectance mode 
with a $4 \mathrm{~cm}^{-1}$ resolution was used to monitor the nature of bonds present in the glass network.

\section{RESULTS AND DISCUSSION}

\subsection{Composition of the Porous BTC-Derived Bioglass Material}

Bentonite clay of the type $(\mathrm{OH})_{4} \mathrm{Si}_{8} \mathrm{Al}_{4} \mathrm{O}_{20} \cdot \mathrm{nH}_{2} \mathrm{O}$ shown in Figure 2(a) was reacted in strong basic medium to initially afford sodium metasilicate (reaction equation is shown elsewhere [26]) after evaporating the alkaline filtrate slowly to dryness at $120^{\circ} \mathrm{C}$. The waterglass obtained, Figure 2(b), from this reaction is hydrolysed under acidic conditions to silicic acid which undergoes condensation to disilicic acid and further reaction to a polycondensed hydrogel [26,27]. The elemental composition of the bioceramic material was adjusted to give a ratio similar to Bioglass ${ }^{\circledR} 45 \mathrm{~S} 5$ by varying the amount of the following reagents; $\mathrm{P}_{2} \mathrm{O}_{5}, \mathrm{NaNO}_{3}$ and $\mathrm{Ca}\left(\mathrm{NO}_{3}\right)_{2} \cdot 4 \mathrm{H}_{2} \mathrm{O}$.

The monolith obtained is shown in Figure 2(c). The weight percentage analysis by AAS of the monolith was confirmed as; (wt\%) $45 \mathrm{SiO}_{2}, 24.5 \mathrm{Na}_{2} \mathrm{O}, 24.5 \mathrm{CaO}, 6$ $\mathrm{P}_{2} \mathrm{O}_{5}$.

\subsection{FTIR Characterisation of the Bioceramic Monolith Similar to Bioglass ${ }^{\circledR} 45 S 5$}

The FTIR spectrum of the BTC-derived bioglass monolith material is shown in Figure 3. It is characterised by a very broad $\mathrm{OH}$ absorption band centred around 3424 $\mathrm{cm}^{-1}$ and a weak absorbed water band at $1650 \mathrm{~cm}^{-1}$ [28]. Two other absorptions bands observed at 905 and 1011 $\mathrm{cm}^{-1}$ correspond to asymmetric Si-O-Si stretching vibration of silanol groups $[29,30]$. The peak centred at 565 $\mathrm{cm}^{-1}$ can be attributed to the P-O bond in crystalline phosphates [31]. Similarly, the weak peak at $1212 \mathrm{~cm}^{-1}$ is attributed to the characteristic vibration of $\mathrm{P}=\mathrm{O}$ bonds. Furthermore, the broad band centred at $1440 \mathrm{~cm}^{-1}$ is diagnostic of the vibrations of non-bridging $\mathrm{PO}_{2}$ in $\mathrm{PO}_{4}^{3-}$ groups or $\mathrm{CO}_{3}^{2-}$ originated from air during the sol-gel fabrication [32]. The vibrational modes obtained for the bioceramic monolith compare with those of biomorphic 45S5 bioglass scaffold [32].

\subsection{XRD Characterisation of the Bioceramic Monolith Similar to Bioglass ${ }^{\circledR}$ 45S5}

$\mathrm{XRD}$ pattern of the BTC-derived bioceramic sintered at $1000^{\circ} \mathrm{C}$ for $2 \mathrm{~h}$ is shown in Figure 4. It can be seen that the material contains both amorphous and crystalline phases. The amorphous phase is characterized by a wave-like tendency in the baseline and diffused peak bottoms caused by the short-range ordering of the silicate structure in the glass [33]. The major crystalline phase $\mathrm{Na}_{2} \mathrm{Ca}_{2} \mathrm{Si}_{3} \mathrm{O}_{9}$ has hexagonal system based on the angular

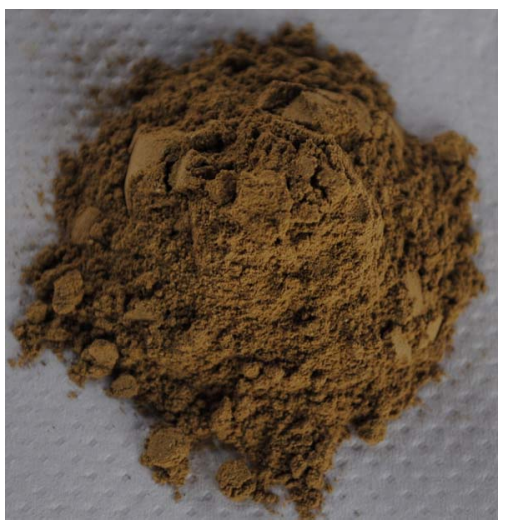

(a)

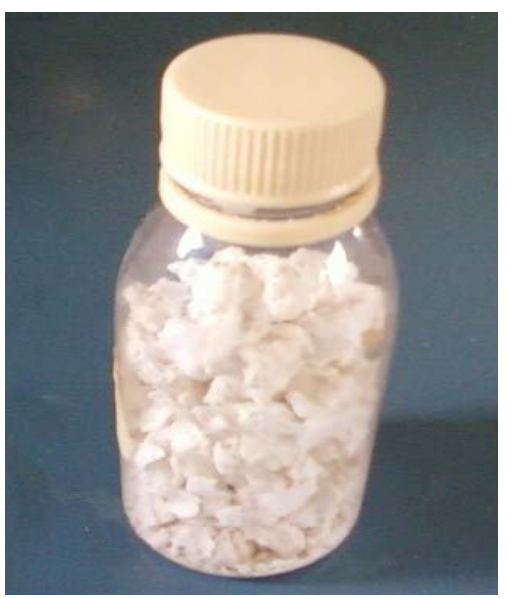

(b)

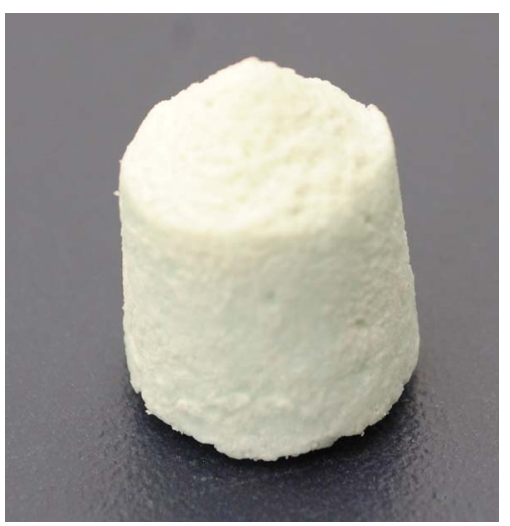

(c)

Figure 2. (a) Bentonite clay; (b) Sodium metasilicate and (c) bioceramic monolith with Bioglass ${ }^{\circledR}$ 45S5 composition.

locations and the intensities of the sharp diffraction peaks which match those of the standard PDF \#22-1455 [16,34]. The same diffraction pattern was reported by previous studies on sintered 45S5 bioactive glass [14-16,32,34].

There are two additional peaks observed at $2 \theta=$ $23.13^{\circ}$ and $32.62^{\circ}$ assigned to the (111) and (211) planes of orthorhombic $\mathrm{NaCaPO}_{4}$ crystal (PDF \#29-1193) [29]. 


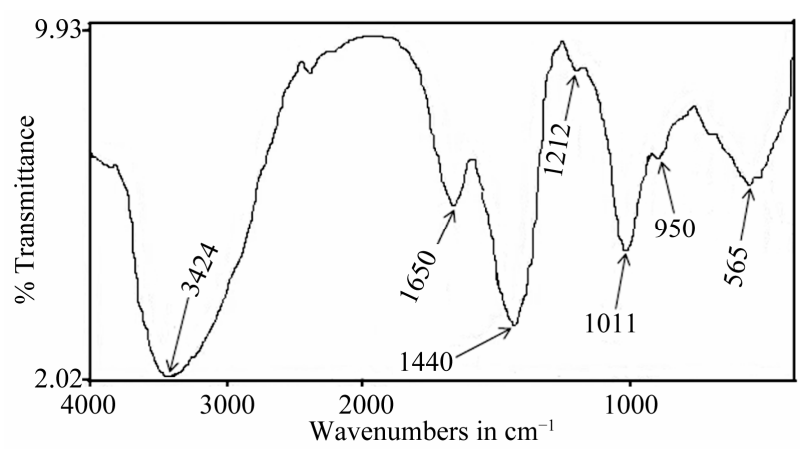

Figure 3. FTIR spectrum of the bioceramic monolith similar to Bioglass ${ }^{\circledR} 45$ S5.

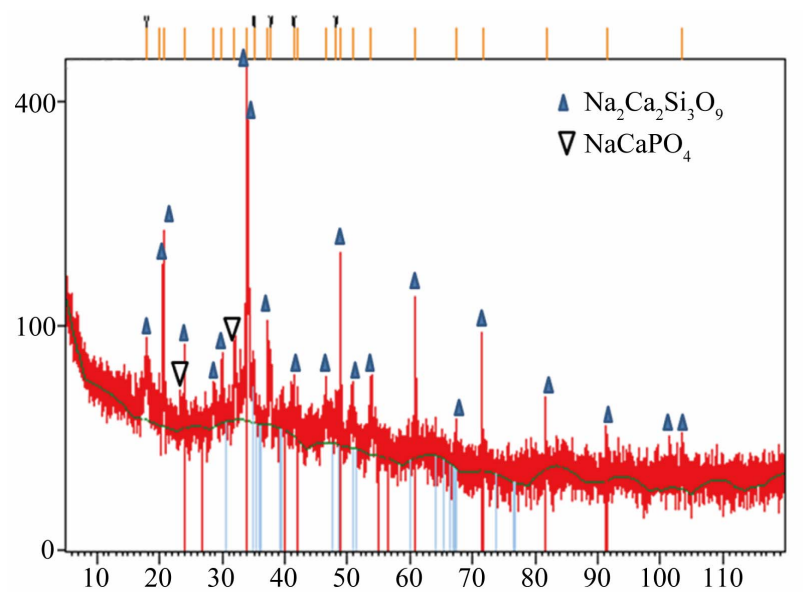

Figure 4. XRD pattern of the bioceramic monolith similar to Bioglass ${ }^{\circledR} 45 \mathrm{~S}$ showing peaks for $\mathrm{Na}_{2} \mathrm{Ca}_{2} \mathrm{Si}_{3} \mathrm{O}_{9}$ and $\mathrm{NaCaPO}_{4}$.

\subsection{Morphology of the Bioceramic Monolith Similar to Bioglass ${ }^{\circledR} 45 \mathrm{~S} 5$}

The porous nature of the BTC-derived bioceramic was investigated using SEM. Figure 5 shows that the material contains prominent macropores, micropores and pore struts. Most of the pores are open and interconnected, with a network of macropores linking the smaller micropores. Many authors agree that a minimum pore size of $100 \mu \mathrm{m}$ is required for fast cell infiltration inside the scaffold material [27]. However, Figures 6(a)-(d) indicate the presence of seemingly widespread microporosity with an average size range of about $2-6 \mu \mathrm{m}$, and macropores that range between $20-70 \mu \mathrm{m}$. Similar morphologies have been reported for 45S5 bioactive glasses sintered up to $1000^{\circ} \mathrm{C}[14,15]$.

Microporosity and the resultant large surface area are crucial to promote diffusion of fluids and nutrients by means of capillary in-growth [29]. The nature of the struts between pores as shown in Figures 6(c) and (d) is evidently thick and dense which is particularly required to enhance the scaffold mechanical strength.

\section{CONCLUSION}

Bioceramic monolith with elemental composition similar to Bioglass ${ }^{\circledR} 45 \mathrm{~S} 5$ has been prepared by the sol-gel process employing bentonite clay as a cheap source of silica. Strong alkaline medium was used to initially obtain sodium metasilicate from the bentonite clay. The metasilicate was subjected to acidic hydrolysis to give the sol.

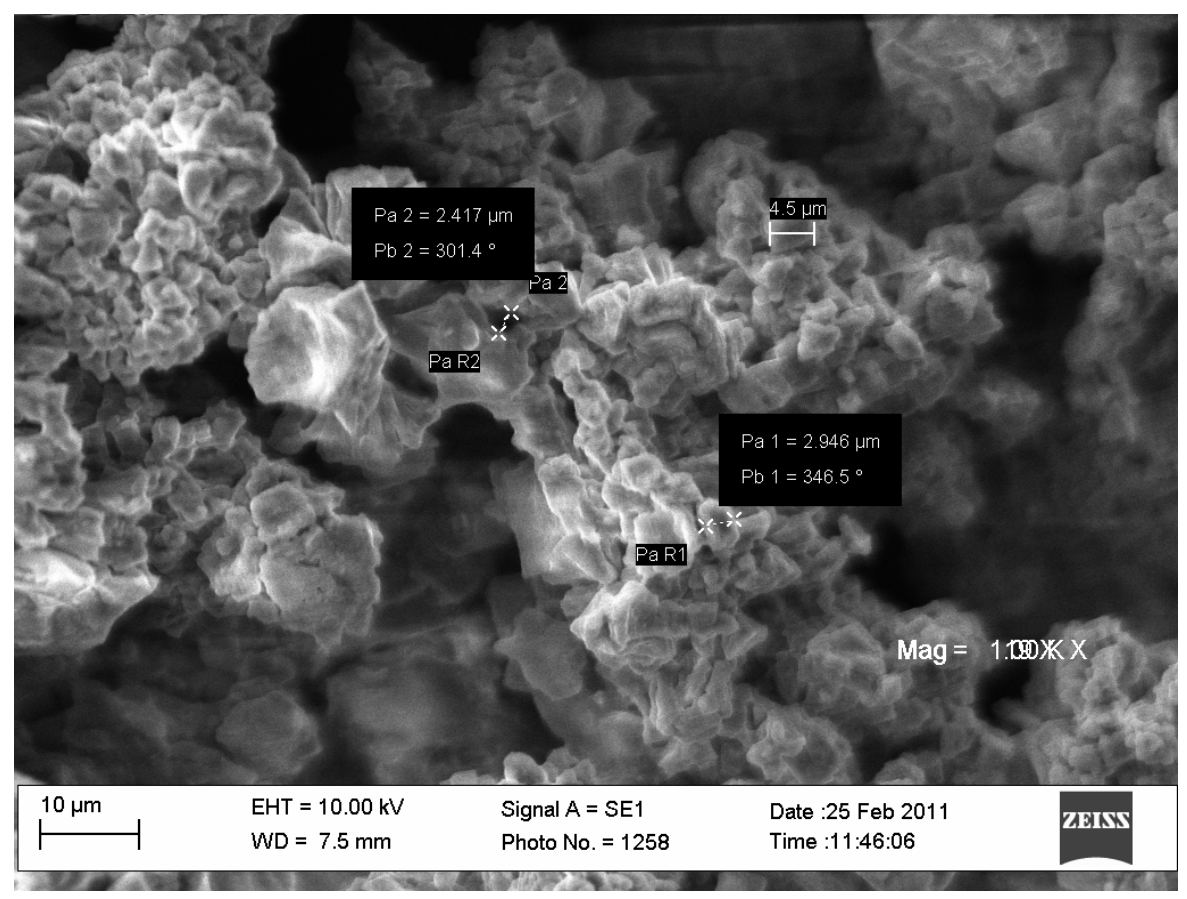

Figure 5. SEM micrograph of BTC-derived bioceramic showing macropores, micropores and pore struts. 

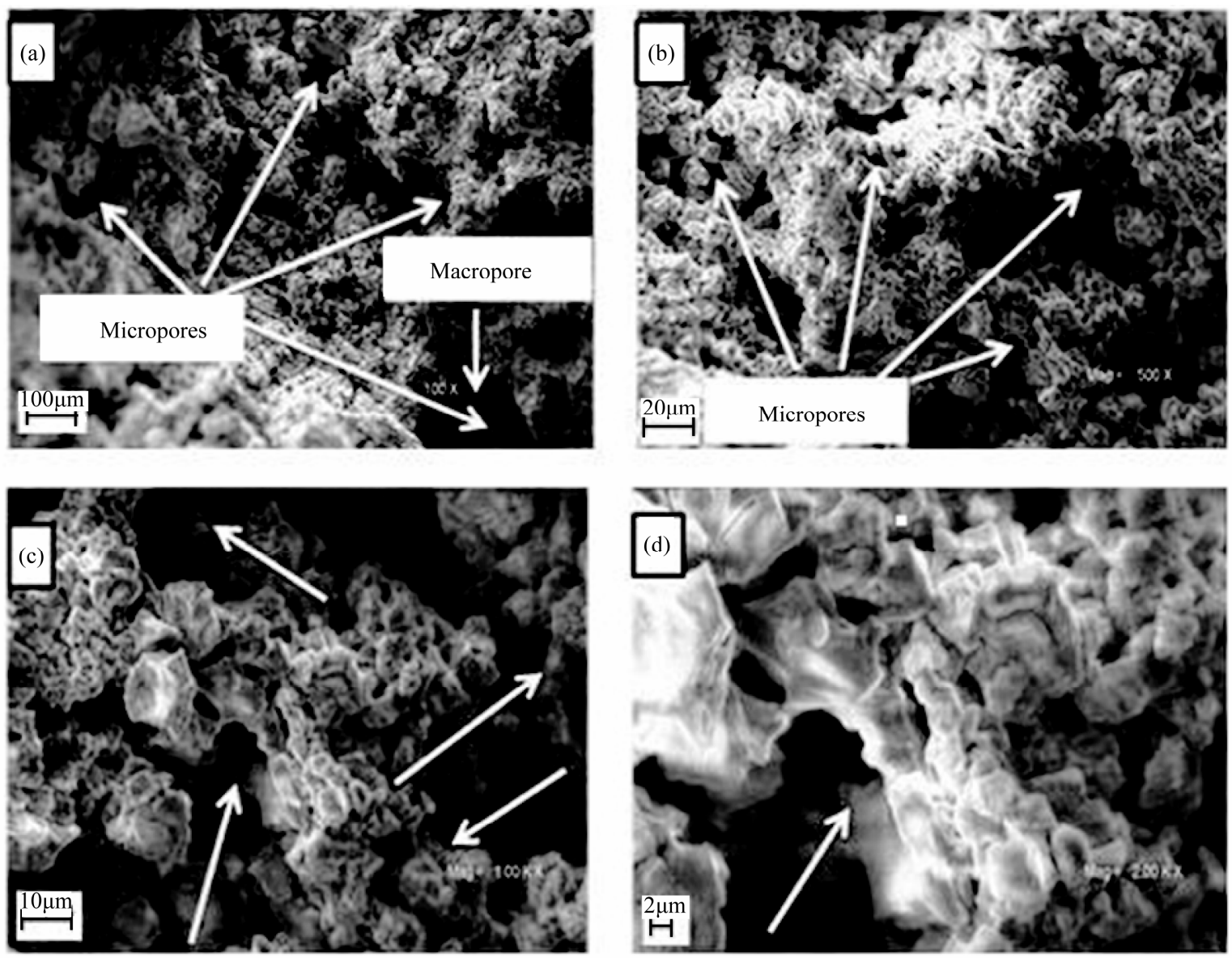

Figure 6. SEM micrographs of the bioceramic at different magnifications. Arrows indicate pores in (a) and (b) and pore struts in (c) and (d).

Thereafter, elemental composition of the sol obtained was adjusted by addition of appropriate inorganic reagents to give the gel that underwent polycondensation reaction that gave a monolith after aging and drying. The monolith was subjected to phase transformation during sintering at elevated temperature to give a major crystal phase identified as $\mathrm{Na}_{2} \mathrm{Ca}_{2} \mathrm{Si}_{3} \mathrm{O}_{9}$ and a secondary crystal phase, orthorhombic $\mathrm{NaCaPO}_{4}$. XRD analysis indicated almost complete conversion of the amorphous phase to a new crystalline phase. Sintering also resulted in densification of the pore struts which is envisioned to enhance the mechanical property. FTIR analysis indicated characteristic absorption bands for Si-O-Si and silanol groups in the framework. SEM analysis however reveals that the pore sizes obtained are smaller than the ideal for bone ingrowth which is between $300-400 \mu \mathrm{m}$. Nevertheless, our results suggest that bentonite clay may serve as low cost raw material for preparing sodium containing bioactive glasses.

\section{ACKNOWLEDGEMENTS}

The authors are grateful to Bells University of Technology, Ota, Nigeria for providing funding and their laboratory for this work.

\section{REFERENCES}

[1] Hench, L.L. (1998) Bioceramics. Journal of American Ceramic Society, 81, 1705-1728. doi:10.1111/j.1151-2916.1998.tb02540.x

[2] Hench, L.L. and Polak, J.M. (2002) Third-generation biomedical materials. Science, 295, 1014-1017. doi:10.1126/science.1067404

[3] Williams, D. (2004) Benefit and risk of tissue engineering. Materials Today, 7, 24-29. doi:10.1016/S1369-7021(04)00232-9

[4] Oliveira, J.M., Silva, S.S., Malafaya, P.B., Rodrigues, M.T., Kotobuki, N., Hirose, M., Gomes, M.E., Mano, J.F., Ohgushi, H. and Reis, R.L. (2009) Macroporous hydroxyapatite scaffolds for bone tissue engineering applications: Physicochemical characterization and assessment of rat bone marrow stromal cell viability. Journal of Biomedical Materials Research Part A, 91A, 175-186. doi:10.1002/jbm.a.32213

[5] Hutmacher, D.W., Schantz, J.T., Lam, C.X.F., Tan, K.C and Lim, T.C. (2007). State of the art and future directions of scaffold-based bone engineering from a biomate- 
rials perspective. Journal of Tissue Engineering and Regenerative Medicine, 1, 245-260.

doi:10.1002/term. 24

[6] Hassna, R.R.R. and Zhang, M. (2004) Biphasic calcium phosphate nanocomposite porous scaffolds for load-bearing bone tissue engineering. Biomaterials, 25, 5171-5180. doi:10.1016/j.biomaterials.2003.12.023

[7] Hench, L.L. (2006) The story of Bioglass ${ }^{\circledR}$. Journal Material Science: Materials in Medicine, 17, 967-978. doi:10.1007/s10856-006-0432-z

[8] Xynos, I.D., Edgar, A.J., Buttery, L.D.K., Hench, L.L. and Polak, J.M. (2001) Gene-expression profiling of human osteoblasts following treatment with the ionic products of Bioglass 45S5 dissolution. Journal of Biomedical Materials Research A, 55, 151-157.

doi:10.1002/1097-4636(200105)55:2<151::AID-JBM100 1>3.0.CO;2-D

[9] Hench, L.L., Splinter, R.J., Allen, W.C. and Greenlee Jr., T.K. (1971) Bonding mechanisms at the interface of ceramic prosthetic materials. Journal of Biomedical Materials Research, 2, 117-141. doi:10.1002/jbm.820050611

[10] Jones, J.R. (2009) New trends in bioactive scaffolds: The importance of nanostructure. Journal of European Ceramic Society, 29, 1275-1281.

doi:10.1016/j.jeurceramsoc.2008.08.003

[11] Hench, L.L. (1991) Bioceramics: From concept to clinic. Journal of American Ceramic Society, 74, 1487-510. doi:10.1111/j.1151-2916.1991.tb07132.x

[12] Jones, J.R., Ehrenfried, L.M. and Hench, L.L. (2006) Optimising bioactive glass scaffolds for bone tissue engineering. Biomaterials, 27, 964-973. doi:10.1016/j.biomaterials.2005.07.017

[13] Pereira, M.M., Jones, J.R., Orefice, R.L. and Hench, L.L. (2005) Preparation of bioactive glass-polyvinyl alcohol hybrid foams by the sol-gel method. Journal of Materials Science: Materials in Medicine, 16, 1045-1050. doi:10.1007/s10856-005-4758-8

[14] Chen, Q.-Z., Thompson, I.D. and Boccaccini, A.R. (2006) 45S5 Bioglass ${ }^{\circledR}$-derived glass-ceramic scaffold for bone tissue engineering. Biomaterials, 27, 2414-2425. doi:10.1016/j.biomaterials.2005.11.025

[15] Chen, Q.-Z., Li, Y., Jin, L., Quinn, J.M.W. and Komesaroff, P.A. (2010) A new sol-gel process for producing $\mathrm{Na}_{2} \mathrm{O}$-containing bioactive glass ceramics. Acta Biomaterialia, 6, 4143-4153. doi:10.1016/j.actbio.2010.04.022

[16] Peitl, O., Zanotto, E.D. and Hench, L.L. (2001) Highly bioactive $\mathrm{P}_{2} \mathrm{O}_{5}-\mathrm{Na}_{2} \mathrm{O}-\mathrm{CaO}-\mathrm{SiO}_{2}$ glass-ceramics. Journal of Non-Crystalline Solids, 292, 115-126. doi:10.1016/S0022-3093(01)00822-5

[17] Li, Z., Hou, B., Xu, Y., Wu, D., Sun, Y., Hu, W., Deng, W. and Deng, F. (2005). Comparative study of sol-gelhydrothermal and sol-gel synthesis of titania-silica composite nanoparticles. Journal Solid State Chemistry, 178, 1395-1405. doi:10.1016/i.jssc.2004.12.034

[18] Pabon, E., Retuert, J., Quijada, R. and Zarate, A. (2004) $\mathrm{TiO}_{2}-\mathrm{SiO}_{2}$ mixed oxides prepared by a combined sol-gel and polymer inclusion method. Microporous and Meso- porous Materials, 67, 195-203.

doi:10.1016/j.micromeso.2003.10.017

[19] Crisan, M., Raileanu, M., Preda, S., Zaharescu, M., Valean, A.M., Popovici, E.J., Teodorescu, V.S., Matejec, V. and Mrazek, J. (2006) Manganese doped sol-gel materials with catalytic properties. Journal of Optoelectronics and Advanced Materials, 8, 815-819.

[20] Hench, L.L., (1997) Theory of bioactivity: The potential for skeletal regeneration. Anales de Quimica, 93, 44-48.

[21] Nayak, J.P., Kamar, S. and Bera, J. (2010) Sol-gel synthesis of bioglass-ceramics using rice husk ash as a source for silica and its characterization. Journal of Non-Crystalline Solids, 356, 1447-1451. doi:10.1016/j.jnoncrysol.2010.04.041

[22] Wu, S.C., Hsu, H.C., Hsiao, S.H. and Ho, W.F. (2009) Preparation of porous 45S5 Bioglass-derived glass-ceramic scaffolds by using rice husk as a porogen additive. Journal of Materials Science: Materials in Medicine, 20, 1229-1236. doi:10.1007/s10856-009-3690-8

[23] Casado, C.E., Prado, M.O. and Zanotto, E.D. (2001) Nanoporosity in sintered silica powders from rice hull ash. II Simpósio Brasilereiro de Estruturologia, Tiradentes, 27-29 September 2001, 89-89.

[24] Sposito, G., Skipper, N.T., Sutton, R., Park, S-h., Soper, A.K. and Greathouse, J.A. (1999) Surface geochemistry of the clay minerals. Proceedings of the National Academy of Sciences of the United States of America, Califonia, 8-9 November 1998, 3358-3364.

[25] Moore, D.M. and Reynolds, R.C. (1997) X-ray diffraction and identification and analysis of clay minerals. 2nd Edition, Oxford University Press, New York.

[26] Essien, E.R., Olaniyi, O.A., Adams, L.A. and Shaibu, R.O. (2012) Sol-gel-derived porous silica: Economic synthesis and characterization. Journal of Minerals and Materials Characterization and Engineering, 11, 976-981.

[27] Karageorgiou, V. and Kaplan, D. (2005) Porosity of 3D biomaterial scaffolds and osteogenesis. Biomaterials, 26, 5474-5491. doi:10.1016/j.biomaterials.2005.02.002

[28] Lee, C.J., Kim, G.S. and Hyun, S.H. (2002) Synthesis of silica aerogels from waterglass via new modified ambient drying. Journal of Materials Science, 37, 2237-2241. doi:10.1023/A:1015309014546

[29] Ochoa, I., Sanz-Herrera, J.A., Garcia-Aznar, J.M., Doblaré, M., Yunos, D.M. and Boccaccini, A.R. (2009) Permeability evaluation of 45S5 Bioglass ${ }^{\circledR}$-based scaffolds for bone tissue engineering. Journal of Biomechanics, 42, 257-260. doi:10.1016/j.jbiomech.2008.10.030

[30] Lenza, R.F.S. and Vasconcelos, W.L. (2001) Preparation of silica by sol-gel method using formamide. Materials Research, 4, 189-194. doi:10.1590/S1516-14392001000300008

[31] Carta, D., Knowles, J.C., Smith, M.E. and Newport, R.J. (2007) Synthesis and structural characterization of $\mathrm{P}_{2} \mathrm{O}_{5^{-}}$ $\mathrm{CaO}-\mathrm{Na}_{2} \mathrm{O}$ sol-gel materials. Journal of Non-Crystalline Solids, 353, 1141-1149. doi:10.1016/j.jnoncrysol.2006.12.093

[32] Qian, J., Kang, Y., Wei, Z. and Zhang, W. (2009) Fabrication and characterization of biomorphic 45S5 bioglass 
scaffold from sugarcane. Material Science and Engineering $C$, 29, 1361-1364.

[33] Chen, Q.Z., Rezewan, K., Françon, V., Armitage, D., Nazhat, S.N., Jones, S.H. and Boccaccini, A.R. (2007) Surface functionalization of Bioglass ${ }^{\circledR}$-derived porous scaffolds. Acta Biomaterialia, 3, 551-562. doi:10.1016/j.actbio.2007.01.008

[34] Clupper, D.C., Mecholsky, J.J., LaTorre, G.P. and Greenspan, D.C. (2002) Bioactivity of tape cast and sintered bioactive glass-ceramic in simulated body fluid. Biomaterials, 23, 2599-2606. doi:10.1016/S0142-9612(01)00398-2 